\title{
Two new species and new records of hyphomycetes from Vietnam
}

\section{Mel'nik VA ${ }^{1}$, Alexandrova $A V^{2}$ and Braun $\mathbf{U}^{3}$}

${ }^{1}$ Laboratory of the Systematics and Geography of Fungi, Komarov Botanical Institute, Russian Academy of Sciences, Professor Popov Street 2, St. Petersburg, 197376, Russia

${ }^{2}$ Moscow State Lomonosov University, Department of Biology, Lenin Hill Street 1, 12, Moscow 119234, Russia and Joint Vietnam-Russian Tropical Research and Technological Centre, Nguyen Van Huyen, Nghia Do, Cau Giau, Hanoi, Vietnam

${ }^{3}$ Martin Luther University, Institute of Biology, Department of Geobotany and Botanical Garden, Herbarium, Neuwerk 21, 06108 Halle (Saale), Germany

Mel'nik VA, Alexandrova AV, Braun U 2014 - Two new species and new records of hyphomycetes from Vietnam. Mycosphere 5(4), 591-600, Doi 10.5943/mycosphere/5/4/11

\begin{abstract}
The new species Craspedodidymum seifertii and Ityorhoptrum biseptatum (Ascomycota, hyphomycetes), collected in Vietnam on bark of unidentified trees, are described, illustrated and compared with similar species. Furthermore, first records of Kumanasamuha sundara, Leuliisinea bambusicola, Piricaudilium lobatum, Pseudogliophragma indicum and Xenosporium africanum from Vietnam are added, including brief discussions and some with illustrations.
\end{abstract}

Key words - Ascomycota - Asexual morphs - Craspedodidymum seifertii sp. nov. - Ityorhoptrum biseptatum sp. nov. - Southeast Asia

\section{Introduction}

Vietnam in Southeast Asia is a tropical country with high biodiversity. A wide range of plant communities and the richness of higher plants provide a multitude of ecological niches and causally determine a similarly high fungal diversity of micromycetes associated with living and dead leaves, bark, wood and other plant components. However, the fungal diversity of Vietnam is insufficiently known and less explored compared with higher plants. Since 2010 Russian mycologists from the Komarov Botanical Institute, Russian Academy of Sciences (St. Petersburg) and Moscow State Lomonosov University have been engaged in comprehensive mycological explorations in Vietnam within the scope of a research program of the Vietnam-Russian Tropical Research and Technological Centre. Many micromycetes have been collected, including several taxonomic novelties and numerous new records for Vietnam (Alexandrova et al. 2013, Mel'nik 2011, 2012a,b, 2013, Mel'nik \& Alexandrova 2013, Mel'nik \& Braun 2013, Mel'nik \& Crous 2014, Melnik et al. 2012, 2013a,b,c,d, 2014). Most of the recorded fungi are rare and several of them represent first recollections after the original descriptions of the taxa concerned. The present contribution to a better knowledge of Vietnamese fungi encompasses two new hyphomycete species and several new records.

\section{Materials \& Methods}

Fresh samples collected during the course of field trips in Vietnam were dried at room 
temperature. Some samples were incubated in a moist chamber (in a Petri dish with moistened filter paper). The material was later examined in distilled water and photographed using a Zeiss microscope, Stemi 2000CS, and Axio Imager A1 equipped with Nomarski differential interference contrast optics. Identification was carried out through comparison with current taxonomic works dealing with the genera and species concerned. The sizes of conidiophores, conidia and other characters are based on 30 measurements per structure with extremes given in brackets. The examined specimens are deposited at the herbarium of the Komarov Botanical Institute, St. Petersburg, Russia (LE), and some duplicates also at DAOM and HAL.

\section{Results}

\section{Taxonomic novelties}

During the course of examinations of new Vietnamese collections of micromycetes, two hyphomycete samples turned out to belong to new, undescribed species.

Craspedodidymum seifertii Melnik, A.V. Alexandrova \& U. Braun, sp. nov.

Figs. 1 MycoBank MB809299

Etymology - the epithet is dedicated to K.A. Seifert, Canadian mycologists, for his outstanding contributions to mycology in general and the book "The Genera of Hyphomycetes" in particular.

Colonies on the natural substrate effuse hairy, dark brown. Conidiophores macronematous, mononematous, solitary, erect, cylindrical-filiform, unbranched, 160-245 $\mu \mathrm{m}$ long, (9-)10-12 $\mu \mathrm{m}$ wide at the base and (4.5-)6-7 $\mu \mathrm{m}$ in upper part (just beneath the conidiogenous cell), wall somewhat thickened, smooth, sparingly septate, brown or olivaceous-brown, paler towards the apex. Conidiogenous cells integrated, terminal, monophialidic, more or less cylindrical, swollen at the subapical region, (18-)22-32 × 10-12 $\mu \mathrm{m}$, with distinct flaring collarette at the apex, formed as rather thin, pale brown and broad open funnel, 8-10 $\mu \mathrm{m}$ diam. at the opening; sometimes with an additional phialide formed by percurrent proliferation through the collarette. Conidia solitary, but adhering in long false fragile chains (up to about 20) when observed in a moist chamber, obovoid, $18-22(-24) \times 13.2-19 \mu \mathrm{m}$, aseptate, hyaline or subhyaline when young, later brown to dark brown, thick-walled, smooth, apex broadly rounded, base truncate, hilum 3-4 $\mu \mathrm{m}$ wide.

Known distribution - Tropical Vietnam, only known from the type collection.

Material examined - Vietnam, Province Lam Dong, Bi dup - Nui Ba Natural Reserve, Giang Ly, cordon Giang Ly, monsoon tropical forest with predominant trees from Ericaceae, Fagaceae, Lauraceae, Theaceae, $12^{\circ} 12^{\prime} 05^{\prime \prime} \mathrm{N}, 108^{\circ} 40^{\prime} 34^{\prime \prime} \mathrm{E}$, on bark of an unidentified tree, 10 Nov 2012, Yu.K. Novozhilov (LE 264189, holotype).

Notes - Rich fructification of the new species was detected on bark after an incubation between 30 and 40 days in a moist chamber. Based on the striking morphological characters of this fungus, its identification as a species of Craspedodidymum Hol.-Jech. (Holubová-Jechová 1972), currently comprising 13 species, was readily possible. A good survey of species assigned to this genus was provided in Yanna et al. (2000), including illustrations of conidia and morphological details given in tabular form. A comparison of the recently collected Vietnamese material with hitherto described Craspedodidymum spp. revealed that a new undescribed species is involved. $C$. seifertii is characterized by having conidia with distinctly truncate base. Among the 13 species assigned to Craspedodidymum, there are only four morphologically comparable species with similar conidia that are truncate at the base, but all of them are easily distinguishable from the new Vietnamese species. C. proliferans V. Rao \& de Hoog (Rao \& de Hoog 1986) is characterized by having much smaller, obovoid, subglobose to trapezoid, aseptate, dark brown conidia, 9.5-13 $\times$ 8.5-12 $\mu \mathrm{m}$. The conidia of C. cubense J. Mena \& Mercado (Mercado \& Mena 1992) are also much smaller, 11.5-15 × 10.5-13 $\mu \mathrm{m}$, subglobose, obovoid or pyriform and dark brown. C. keniense (P.M. Kirk) Bhat \& W.B. Kendr. (Bhat \& Kendrick 1993) is readily distinguishable by its (0-) 1septate, shorter and above all much narrower conidia, 11-18 $\times(6-) 7-9 \mu \mathrm{m}$, which are brown, 


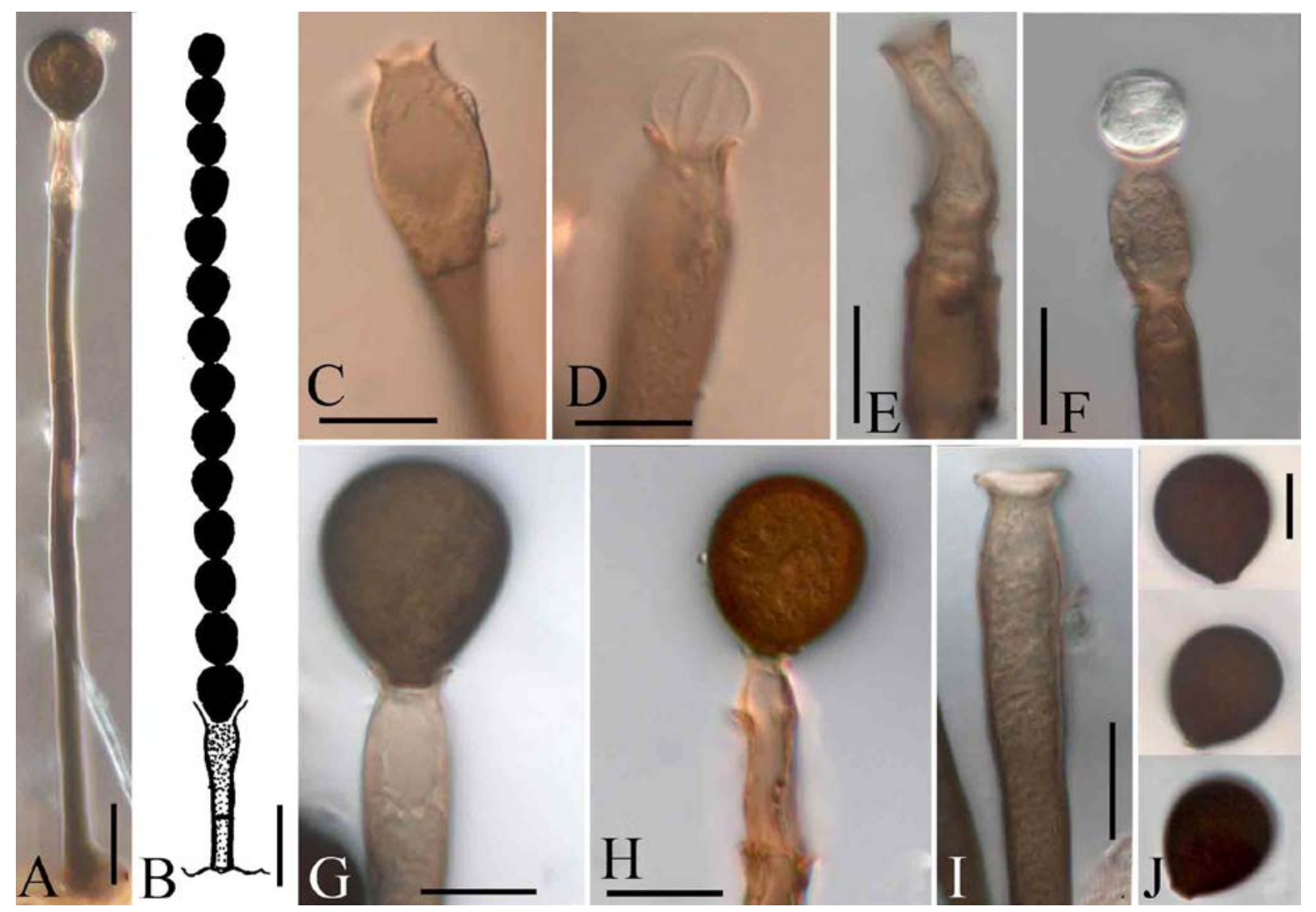

Figs. 1 - Craspedodidymum seifertii. A Conidiophore with single conidium. B Conidia in moist chamber aggregated as false chain. C-E, I Conidiogenous cells. F Conidiogenous cell with young conidium. G-H Conidiogenous cell with mature conidia. J Conidia. Bars: A $=20 \mu \mathrm{m}, \mathrm{B}=30 \mu \mathrm{m}$, $\mathrm{C}-\mathrm{J}=10 \mu \mathrm{m}$.

broadly ellipsoid to obovoid, sometimes truncate at the base. C. nigroseptatum Yanna, Wai H. Ho, Goh \& K.D. Hyde (Yanna et al. 2000) is quite distinct from C. seifertii by its broadly ellipsoidal to obovoid, 3(-4)-septate, much longer conidia, 24-30 × 13-19 $\mu \mathrm{m}$, with dark brown distal and pale brown basal cells.

Ityorhoptrum biseptatum Melnik, A.V. Alexandrova \& U. Braun, sp. nov.

Fig. 2 MycoBank MB809300

Etymology - epithet referring to the 2-septate conidia.

Conidiophores macronematous, mononematous, erect, straight, subcylindrical-filiform, about 140-160 $\mu \mathrm{m}$ long, 8-12 $\mu \mathrm{m}$ at the base, 5-7 $\mu \mathrm{m}$ in the middle, and 3.5-4.2 $\mu \mathrm{m}$ at the apex, with up to 12 conspicuous proliferations, wall somewhat thickened, smooth, pale brown to brown, paler towards the apex. Conidiogenous cells integrated, terminal, monoblastic, conidiogenous loci truncate, about 4-4.5 $\mu \mathrm{m}$ broad, neither thickened nor darkened, later intercalary after monopodial (percurrent) proliferation. Conidia acrogenous, solitary, later remaining attached to the side of the conidiophores, obovoid to clavate or cuneate-obovoid, with more or less spherical apical cell, 16$20 \times(8-) 9-10 \mu \mathrm{m}, 2$-septate, more or less constricted at the septa, upper septum with wide black band, upper cell verruculose, dark brown, median cell smooth, brown, basal cell smooth, subhyaline to pale brown, base truncate, hila 4-4.5 $\mu \mathrm{m}$ wide, with minute (almost invisible) marginal frill.

Known distribution - tropical Vietnam, only known from the type collection.

Material examined - Vietnam, Province Dong Nai, Cat Tien National Park, Ta Lai, road to Bao Sao lake, monsoon tropical forest with members of Sterculia, Syzigium, Haldina, Hopea, and Ficus, $11^{\circ} 26^{\prime} 16^{\prime \prime} \mathrm{N}, 107^{\circ} 25^{\prime} 19^{\prime \prime} \mathrm{E}$, litter, on bark of a branch of an unidentified tree, 15 Nov 2011 , Yu.K. Novozhilov (LE 264188 - holotype). 

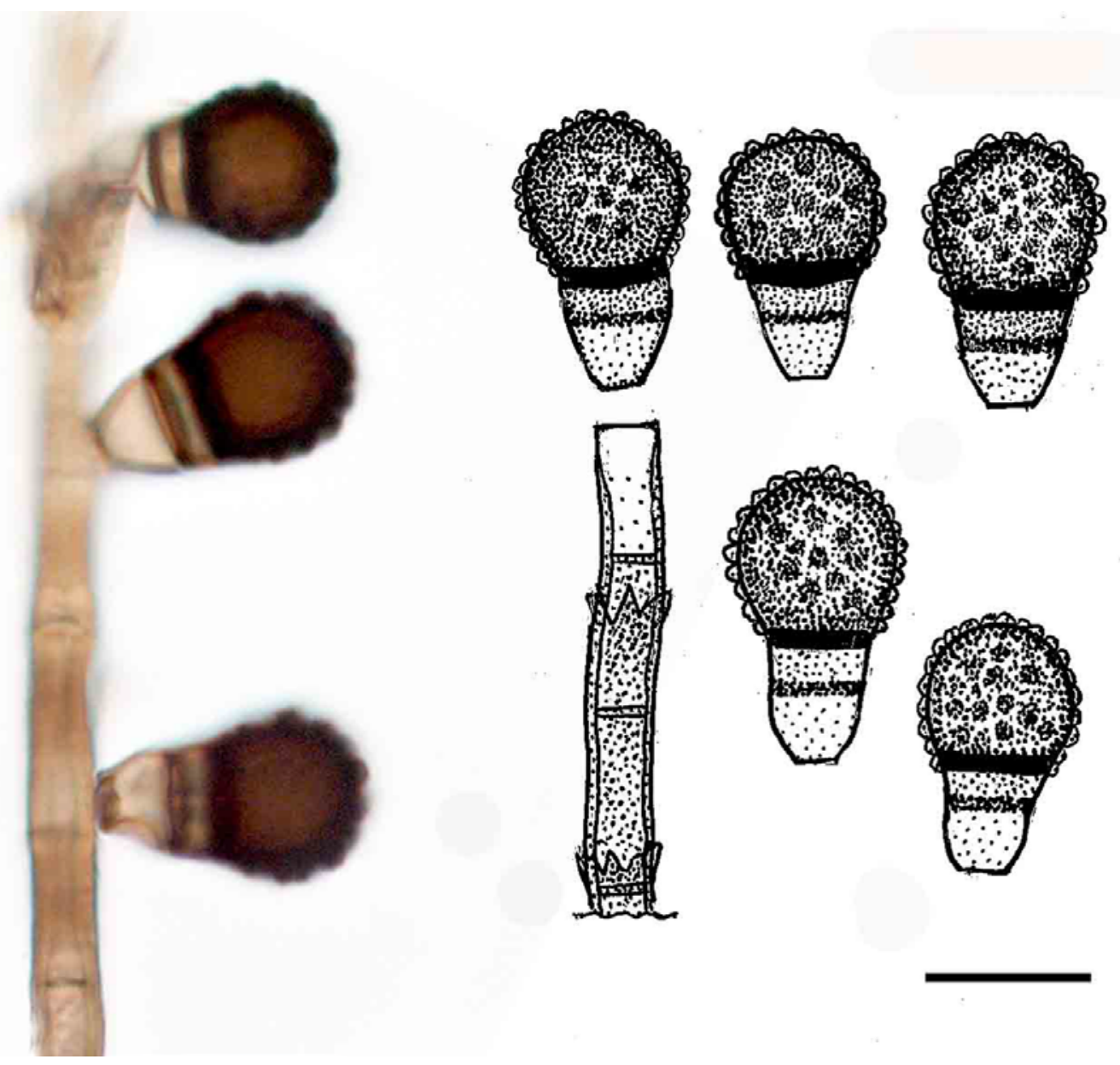

Fig. 2 - Ityorhoptrum biseptatum. Conidia and conidiophores. Bar $=10 \mu \mathrm{m}$.
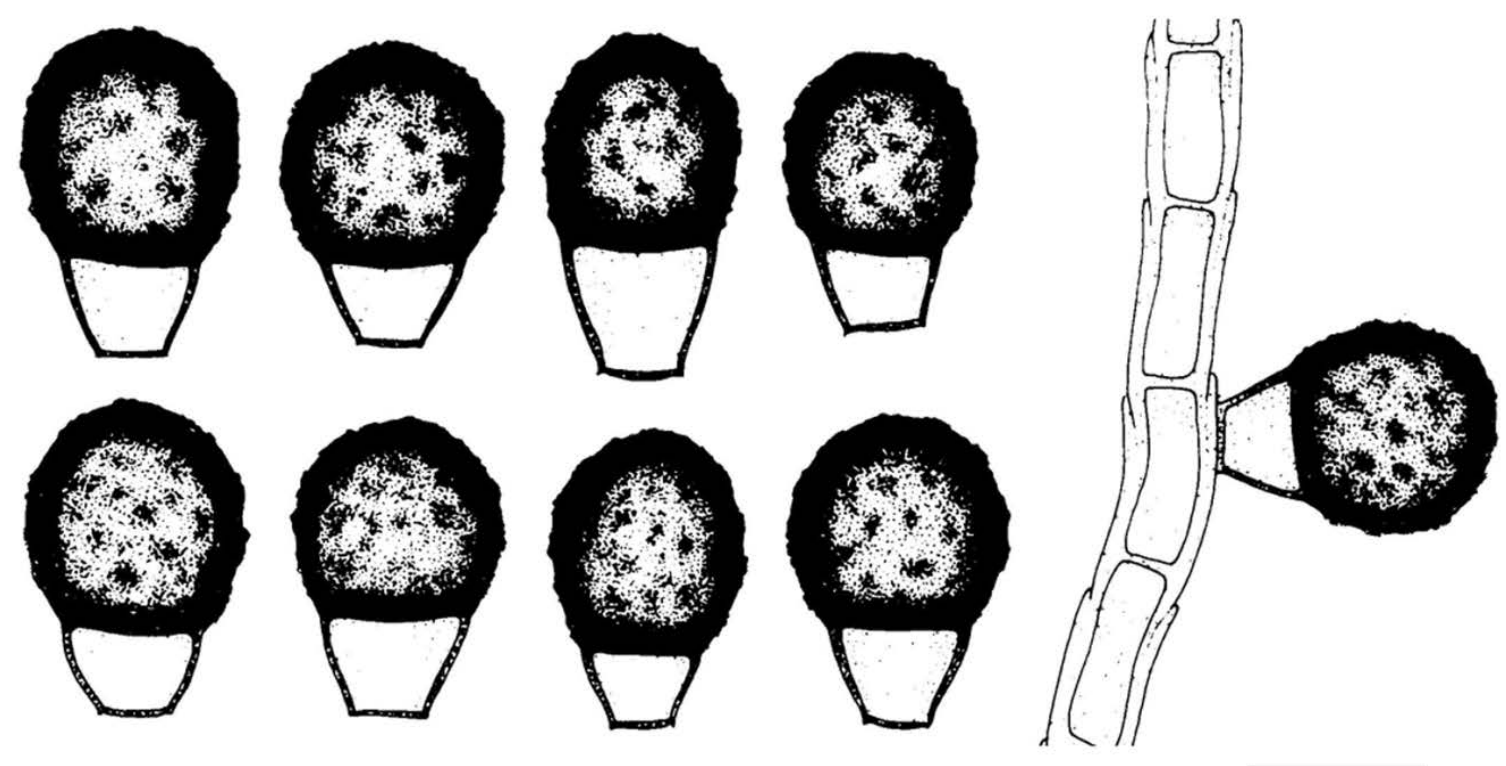

Fig. 3 - Ityorhoptrum verruculosum. Conidia and part of a conidiophore with lateral conidium. Bar $=10 \mu \mathrm{m}$. This picture, copied from Studies in Mycology 28, 12, fig. 7, 1986, is copyright of CBSKNAW Fungal Biodiversity Centre, Utrecht, The Netherlands (reproduced with permission). 
Notes - Based on macronematous, mononematous conidiophores, repeatedly percurrently proliferating, leaving numerous frilled annellations just above each conidiophore septum, monoblastic conidiogenous cells and solitary, verrucose conidia, the present dematiaceous hyphomycete from Vietnam was easily assignable to the genus Ityorhoptrum P.M. Kirk, introduced by Kirk (1986) for a single species, I. verruculosum (M.B. Ellis) P.M. Kirk (Fig. 3). The conidia of the later species are, however, terminally formed and remain attached to the side of the conidiophore. They are obovoid, 1-septate, and the apical cell is more or less spherical, brown, with strongly thickened, verrucose wall, contrasting the basal cell which is smooth, pale brown, only with slightly thickened wall, obconically truncate at the base and with a small persistent, irregular frill (Hughes 1979, Kirk 1986, Rao \& de Hoog 1986, Wu \& Zhuang 2005, Whitton et al., 2012). The conidiophores of Ityorhoptrum natalense W.A. Baker \& Partr. (Partridge et al., 1999), described from decaying wood collected in South Africa, resemble those of I. verruculosum, but the conidia are narrowly obovoid to short clavate, smooth and 0-1-septate. I. sphaericosporum Whitton, McKenzie \& K.D. Hyde (Whitton et al. 2012), found on decaying leaves of Freycinetia banksii in New Zealand, is quite distinct from the new Vietnamese species by its spherical, aseptate, irregularly verrucose conidia.

\section{Key to Ityorhoptrum species}

1. Conidia spherical, aseptate, irregularly verrucose, brown to dark brown, 12.5-17 $\mu \mathrm{m}$ diam.......

1. Conidia septate

I. sphaericosporum

2. Conidia smooth, $0-1$-septate, narrowly obovoid to short clavate, distal cell brown, proximal cell pale brown, $11-14 \times 5-7 \mu \mathrm{m}$

I. natalense

2. Conidia verruculose, $1-2$ septate

3. Conidia 1-septate, not constricted at the septum, obovoid to clavate, upper cell verruculose, brown to dark brown, basal cell pale brown, smooth, 15-22 × 10-13 $\mu \mathrm{m}$ I. verruculosum

3. Conidia 2-septate, more or less constricted at the septa, obovoid to clavate or cuneate-obovoid, upper septum with wide black band, upper cell verruculose, dark brown, median cell smooth, brown, basal cell smooth, subhyaline to pale brown, narrower, 16-20 × (8-)9-10 $\mu \mathrm{m}$

I. biseptatum

\section{New records of hyphomycetes for Vietnam}

Besides the two new species described above, numerous additional asexual ascomycetes recently collected in Vietnam have been identified, including several which proved to be new to Vietnam and in most case rarely collected and reported at all. Some of them are briefly discussed below.

Clasterosporium scleriae M.B. Ellis

Material examined - Vietnam, Province Dak Lak, Chu Yang Sin National Park, montane polydominant tropical forest with trees from Fagaceae, Magnoliaceae, Theaceae, Podocarpaceae, roadside of a forest road, $12^{\circ} 23^{\prime} 47^{\prime \prime} \mathrm{N}, 108^{\circ} 20^{\prime} 57^{\prime \prime}$ E, on leaves of Scleria terrestris (Cyperaceae), 21 Mar 2013, A.V. Alexandrova (LE 264128).

Known distribution - on Scleria spp., Africa (Sierra Leone and Uganda [Ellis 1971]) and Asia (Vietnam, this report).

Notes - This is the first record of this species from Vietnam and only the third worldwide.

\section{Kumanasamuha sundara P.Rag. Rao \& D. Rao}

Material examined - Vietnam, Province Lam Dong, District Bao Lam, Bao Lam forestry, Bao Lam wood, $21 \mathrm{~km} \mathrm{NW}$ to montane Bao Lok, submontane polydominant tropical forest with trees of the Annonaceae, Fagaceae, Magnoliaceae, Myrtaceae, Lauraceae and Theaceae, 11 ${ }^{\circ} 44^{\prime 3}$ " N, 107²4'19" E, 15 Apr 2013, on wood of an unknown tree, A.V. Alexandrova (LE 264184). 
Known distribution - on wood and bark, Africa (Gabon [unpublished material deposited as K (M) IMI 132100]; "French Equatorial Africa” [Ellis 1971]; Seychelles [Mel'nik 1983]), Asia (India, type collection; Japan [Matsushima 1975, Hosoya et al. 2006]; Sri Lanka [unpublished material, CBS 488.73 and CBS H-1375]; Taiwan [Kirschner et al. 2001]), Vietnam (present report).

Notes - This is the first record of this species from Vietnam.

\section{Leuliisinea bambusicola Matsush.}

Figs. 4

Material examined - Vietnam, Province Dong Nai, National Park of Cat Tien, along the

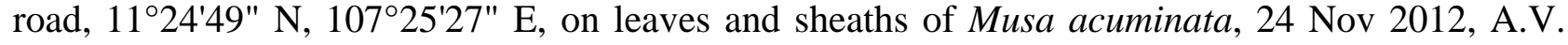
Alexandrova (LE 264109).

Known distribution - on decaying leaves and stems of Phyllostachys edulis (Poaceae), Musa acuminata and M. × paradisiaca (Musaceae), Asia (Taiwan [Matsushima 1985, 1987], Vietnam [present report]), Australia (Queensland [Matsushima 1989]).

Notes: This is the first record for this species from Vietnam.

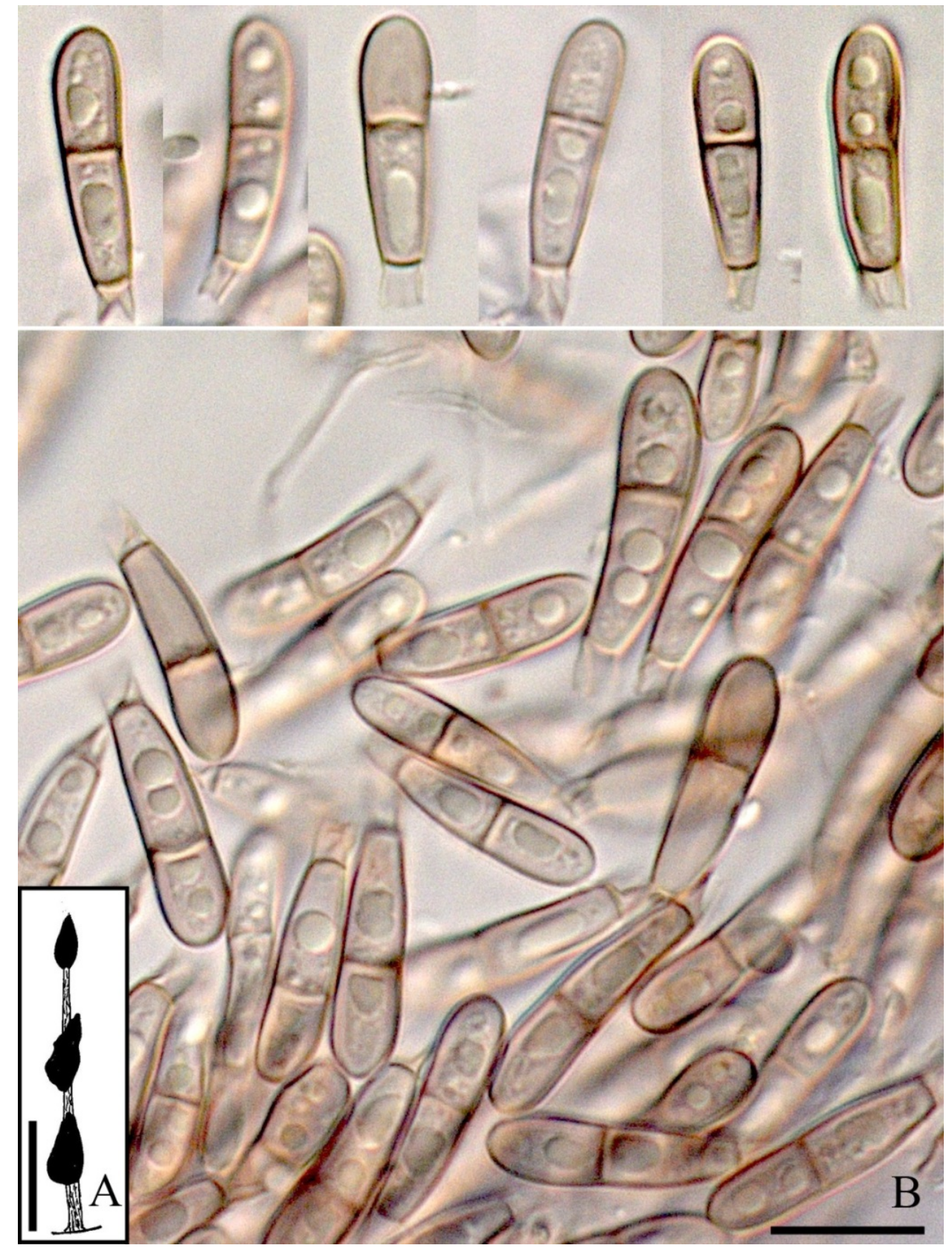

Figs. 4 - Leuliisinea bambusicola. A Synnema. B Conidia. Bars: A $=400 \mu \mathrm{m}, \mathrm{B}=10 \mu \mathrm{m}$. 
Piricaudilium lobatum Hol.-Jech.

Material examined - Vietnam, Province Lam Dong, District Bao Lam, Bao Lok forestry, Bao Lam wood, submontane polydominant tropical forest with members of families Annonaceae,

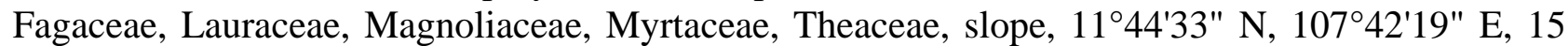
Apr 2013, on decaying leaves of Korthalsia sp. (Arecaceae), A.V. Alexandrova (LE 264136, duplicate in HAL 2655 F).

Known distribution - on dead branches, leaves and petioles of Arecaceae (palms, including Chamaedorea sp. and Korthalsia sp.), Musaceae (Musa sp.), Pandanaceae (including Freycinetia and Pandanus) and Tillandsiaceae (Tillandsia sp.), Asia (Brunei Darussalam [Whitton et al. 2012], Vietnam, present record), New Zealand [Whitton et al. 2012], North America (Mexico [Abarca et al. 1997, Abarca \& Mercado-Sierra 1998]), West Indies (Cuba [Holubova-Jechova 1988, DelgadoRodriguez et al. 2002 and CBS H-4357, strain CBS 591.88, on palm tree, unpublished record]).

Notes - This is the first Vietnamese record of this rarely encountered hyphomycete, originally described from Cuba on dead branches of an unidentified liana (Holubova-Jechova, 1988). Striking characters of this fungus are small, sharp spines around the basal porus of the conidium (left over after tretic conidiogenesis) and conidial body filled with a branching network of hyaline filaments which are more or less visible under high magnification. Instructive illustrations are available in Holubova-Jechová's (1988) original paper and in Seifert et al. (2011: 865, plate 383D).

Pseudogliophragma indicum Phadke \& V.G. Rao [as "indica”]

Figs. 5

Material examined - Vietnam, Province Dong Nai, Cat Tien National Park, right bank of the Dong Nai river (upper stream) near "Lagerstroemia" experimental plot, in tropical monsoon forest with Ficus sp., Lagerstroemia calyculata, Dalbergia multiflora and numerous large lianas, $11^{\circ} 25^{\prime} 42^{\prime \prime} \mathrm{N}, 107^{\circ} 25^{\prime} 32^{\prime \prime} \mathrm{E}$, on bark of unknown large liana, Yu.K. Novozhilov, 25 Jan 2011 (DAOM 242182, LE 264187).

Known distribution - on twigs of Mangifera indica and bark of an unknown liana, Asia (India, Vietnam).

Notes - This is the first Vietnamese record of this rare species, originally described from India on twigs of Mangifera indica (Phadke \& Rao 1980) and the third worldwide.

\section{Xenosporium africanum Piroz.}

Material examined - Vietnam, Province Dong Nai, National Park Cat Tien, moonsoon tropical forest, close to "Lagerstroemia" plot, predominated by Lagerstroemia calyculata, Haldina cordifolia, Tetrameles nudiflora, Hopea odorata, Sindora siamensis, Afzelia xylocarpa, $11^{\circ} 25^{\prime} 43^{\prime \prime}$ N, 107²5'38" E, on leaves of Calamus sp. (Arecaceae), litter, 28 Dec 2010, A.V. Alexandrova (LE 264150); Province Lam Dong, forestry Bao Lok, wood Bao Lam, submontane tropical forest predominated by members of Annonaceae, Fagaceae, Lauraceae, Magnoliaceae, Myrtaceae,

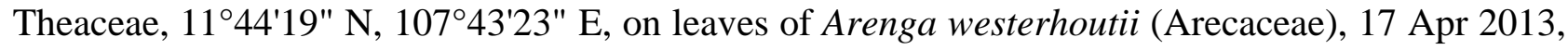
A.V. Alexandrova (LE 264151); Province Lam Dong, forestry Bao Lok, wood Bao Lam, submontane tropical forest predominated by members of Annonaceae, Fagaceae, Lauraceae, Magnoliaceae, Myrtaceae, Theaceae, $11^{\circ} 43^{\prime} 04^{\prime \prime}$ N, 107²'32" E, on leaves of Symplocos sp., (Symplocaceae), 18 Apr 2013, A.V. Alexandrova (LE 264152); Province Dong Nai, Cat Tien National Park, sector Nam Cat Tien, Ta Lai, road to lake Bao Sao, high forest with trees from

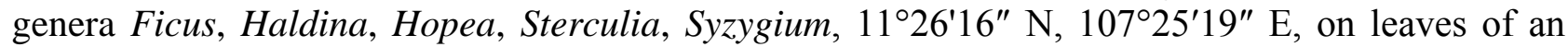
unidentified tree, 16 Nov 2011, A.V. Alexandrova (LE 264153).

Known distribution - on leaf litter and dead wood, Africa (Tanzania [Goos 1990]), Asia (China [Zhao et al. 2007], India [Goos 1990], Vietnam [the present records]).

Notes - Xenosporium africanum was described on a dead rachis of Elaeis guineensis from Tanzania (Deighton \& Pirozynski 1966). Additional records of this species on dead wood are from India (Goos 1990) and China (Zhao et al. 2007). The present collections of this species from Vietnam represent first records for this country. 


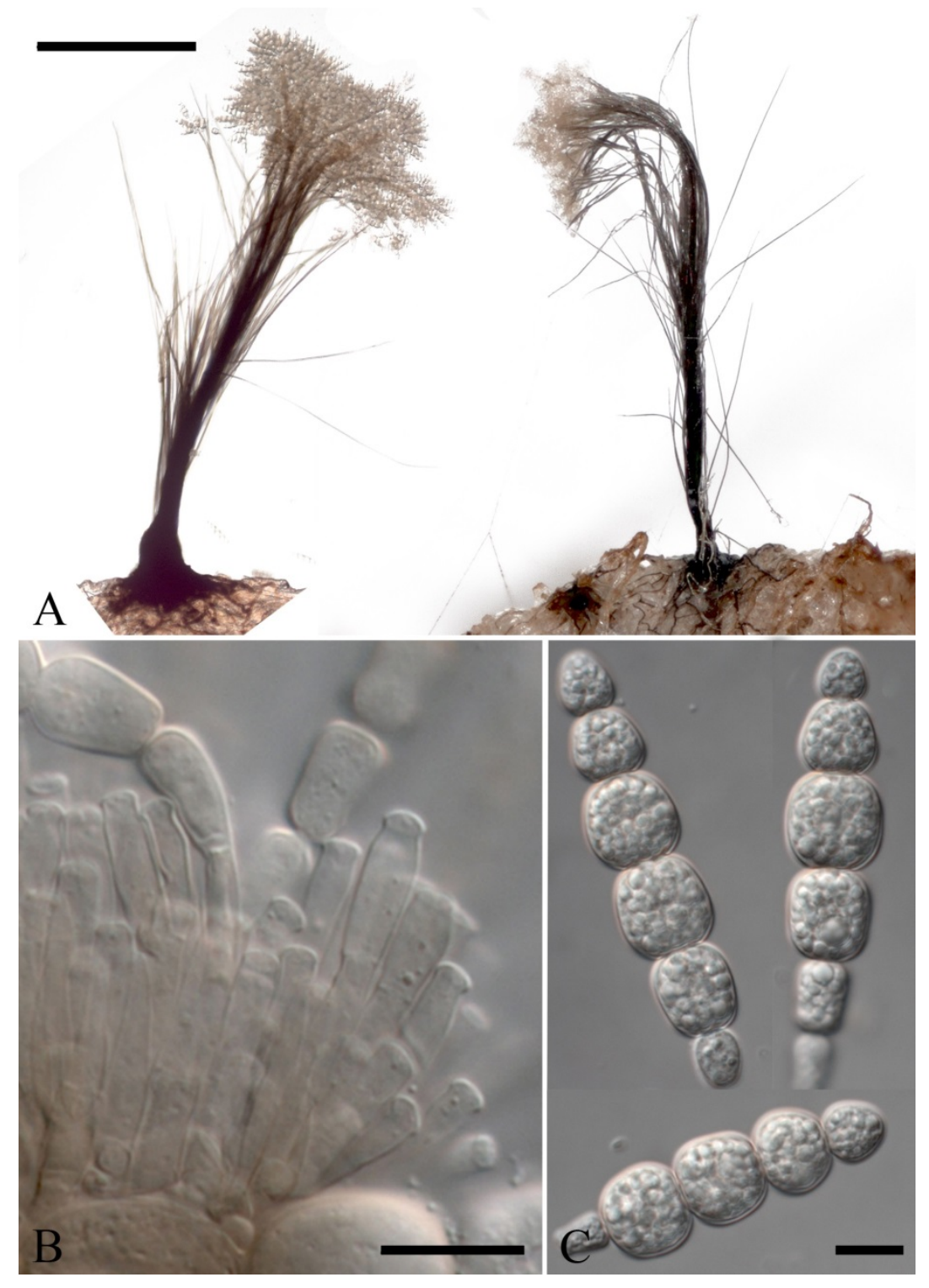

Figs. 5 - Pseudogliophragma indicum. A Synnemata. B Conidiogenous cells. C Conidia. Bars: $\mathrm{A}=$ $500 \mu \mathrm{m}, \mathrm{B}=20 \mu \mathrm{m}, \mathrm{C}=10 \mu \mathrm{m}$.

\section{Acknowledgements}

Yuri Novozhilov and Eugene Popov, St. Petersburg, Russia, are thanked for micrographs and the preparation of photoplates, and we are much obliged to Yuri Novozhilov for providing his fungal collections from Vietnam.

\section{References}

Abarca GH, Mena Portales J, Mercado-Sierra A, Reyes Estebanez M. 1997 - Tropical hyphomycetes of Mexico. II. Some species from the tropical biology station "Los Tuxtlas", Veracruz, Mexico. Mycotaxon 64, 203-223.

Abarca GH, Mercado-Sierra A. 1998 - Tropical Hyphomycetes of Mexico. III. Some species from the Calakmul Biosphere Reserve, Campeche. Mycotaxon 68, 137-143.

Alexandrova AV, Braun U, Mel'nik VA. 2013 - Pyricularia contorta sp. nov. - a new species from Vietnam. Schlechtendalia 25, 73-76. 
Bhat DJ, Kendrick B. 1993 - Twenty-five new conidial fungi from the western Ghat and Andaman islands (India). Mycotaxon 49, 19-90.

Deighton FC, Pirozynski KA. 1966 - Microfungi II. Brooksia and Grallomyces; Acrogenotheca ornata sp. nov.; the genus Xenosporium. Mycological Papers 105, 1-35.

Delgado-Rodruguez G, Mena-Portales J, Calduch M, Decock C. 2002 - Hyphomycetes (hongos microscopicos) del area proteggida mil cumbre, Cuba Occidental. Cryptogamie Mycologie 23, 277-293.

Ellis MB. 1971 - Dematiaceous Hyphomycestes. Commonwealth Mycological Institute, Kew.

Goos RD. 1990 - Review of the anamorph genus Xenosporium. Mycologia 82, 742-752.

Holubová-Jechová V. 1972 - Craspedodidymum, a new genus of phialosporous Hyphomycetes. Česká Mykologie 26, 70-73.

Holubová-Jechová V. 1988 - Studies on Hyphomycetes from Cuba VIII. A new genus Piricaudilium and some species new for the territory of Cuba. Česká Mykologie 42, 200-204.

Hosoya T, Degawa Y, Doi Y. 2006 - Fungi of the Sagami Sea Shore, Central Japan. Memoirs of the National Science Museum, Tokyo 42, 239-245.

Hughes SJ. 1979 - Relocation of species of Endophragmia auct. with notes on relevant generic names. New Zealand Journal of Botany 17, 139-188.

Kirk PM. 1986 - New or interesting microfungi. XV. Miscellaneous hyphomycetes from the British Isles. Transactions of the British Mycological Society 86, 409-428.

Kirschner R, Chen ZC, Oberwinkler F. 2001 - New records of ten species of hyphomycetes from Taiwan. Fungal Science 16, 47-62.

Matsushima T. 1975 - Icones Fungorum a Matsushima Lectorum. Published by the author.

Matsushima T. 1985 - Matsushima Mycological Memoirs. Vol. 4. Published by the author.

Matsushima T. 1987 - Matsushima Mycological Memoirs. Vol. 5. Published by the author.

Matsushima T. 1989 - Matsushima Mycological Memoirs. Vol. 6. Published by the author.

Mel'nik VA, Alexandrova AV. 2013 - New and rare anamorphic fungi in the mycobiota of South Vietnam. Materialy mezhdunarodnoy nauchnoy konferentsii «Problemy mikologii i fitopatologii v XXI veke», 2-4 oktyabrya 2013, Sankt-Peterburg, 180-183 (in Russian).

Mel'nik VA, Braun U, Alexandrova AV. 2013a - Dactylaria mucoglobifera sp. nov. - a new species from Vietnam. Schlechtendalia 25, 47-52.

Mel'nik VA, Braun U. 2013 - Atractilina alinae sp. nov. and Neosporidesmium vietnamense sp. nov. - Two new synnematous hyphomycetes from Vietnam. Mycobiota 3, 1-9.

Mel'nik VA, Castañeda-Ruiz RF, Granados M. 2013b - New species of Heliocephala from Vietnam. Mycotaxon 123, 281-284.

Mel'nik VA, Crous PW. 2014 - Braunomyces dictyosporus gen. sp. nov. from Vietnam. IMA Fungus 5, 1-5.

Mel'nik VA, Novozhilov Yu, Popov ES, Alexandrova AV, Kuznetsov AN, Kovalenko AE. 2014 Anamorphic fungi of Vietnam. V. Mikologiya i Fitopatologiya 48, 181-193 (in Russian).

Mel'nik VA, Novozhilov YuK, Popov ES, Alexandrova AV, Kovalenko AE. 2013c - Anamorphic fungi of Vietnam. III. Mikologiya i Fitopatologiya 47, 316-320 (in Russian).

Mel'nik VA, Novozhilov YuK, Popov ES, Alexandrova AV, Kuznetsov AN, Kovalenko AE. 2013d - Anamorphic fungi of Vietnam. IV. Mikologiya i Fitopatologiya 47, 381-389 (in Russian).

Mel'nik VA, Novozhilov YuK, Popov ES, Alexandrova AV. 2012 - Anamorphic fungi of Vietnam. II. Mikologiya i Fitopatologiya 46, 247-256 (in Russian).

Mel'nik VA. 1983 - Some materials on Fungi imperfect occurring in tropical areas I. Mikologiya i Fitopatologiya. 17, 36-42 (in Russian).

Mel'nik VA. 2011 - Anamorphic fungi of Vietnam. I. Mikologiya i Fitopatologiya 45, 323-331 (in Russian).

Mel'nik VA. 2012a - A new species of Ardhachandra (hyphomycetes) from Vietnam. Mycosphere 3, 922-924. 
Mel'nik VA. 2012b - Phaeoisaria vietnamensis sp. nov. and P. clematidis (hyphomycetes) from Vietnam. Mycosphere 3, 957-960.

Mel'nik VA. 2013 - Three species of hyphomycetes new for mycobiota of Vietnam. Novosti Sistematiki Nizshikh Rasteniy 47, 122-126 (in Russian).

Mercado SA, Mena PJ. 1992 - Nuevos o raros hifomycetes de Cuba VII. Especies enteroblásticas. Acta Botanica Hungarica 37, 63-73.

Partridge EC, Baker W, Morgan-Jones G, Eicker A. 1999 - Notes on hyphomycetes. LXXV. New species of Brachysporiella and of the previously monotypic genus Ityorhoptrum on decorticated wood in southern Africa. Mycotaxon 73, 303-311.

Phadke CH, Rao VG. 1980 - Pseudogliophragma, a new genus of Hyphomycetes. Norwegian Journal of Botany 27, 127-130.

Rao V, de Hoog GS. 1986 - New or critical Hyphomycetes from India. Studies in Mycology 28, 184.

Seifert KA, Morgan-Jones G, Gams W, Kendrick B. 2011 - The Genera of Hyphomycetes. CBS Biodiversity Series 9, 1-997.

Whitton SR, McKenzie EHC, Hyde KD. 2012 - Fungi associated with Pandanaceae. Fungal Diversity Research Series 21, 1-457.

Wu WP, Zhuang WY. 2005 - Sporidesmium, Endophragmiella and related genera from China. Fungal Diversity Research Series 15, 1-351.

Yanna, Ho WH, Goh TK, Hyde KD. 2000 - Craspedodidymum nigroseptatum sp. nov., a new hyphomycete on palms from Brunei Darussalam. Mycological Research 104, 1146-1151.

Zhao GZ, Liu XZ, Wu WP. 2007 - Helicosporous hyphomycetes from China. Fungal Diversity 26, 313-524. 